\title{
A GENERAL OUTLOOK ON EMPLOYMENT OF THE DISABLED UNDER THE PERSPECTIVE OF DECENT WORK
}

\author{
Sanem BERKÜN* \\ Özlem IŞIĞIÇOK ${ }^{* *}$
}

\begin{abstract}
The decent work that is stated to be an international objective by ILO has become a global need and demand concerning all individuals today. With the change in perception towards the disabled, new strategies to contend with the problems the disabled face within work life are developed in many countries. The social policies developed intend to help the disabled to be employed in jobs related with their skills and conditions and to keep them. In this context, it is aimed to take all the necessary measures for the disabled to have economical, social and psychological satisfaction and remove the obstacles that prevent the disabled to be socially integrated. The intend that is set is highly compatible with the objectives aimed for the 'decent work' notion. The study draws attention to this consistency and to the importance of employment for the disabled to be socially integrated.
\end{abstract}

Keywords: Decent Work, The Disabled, Employment, Work life, ILO

\section{INSSAN ONURUNA YAKIŞIR ISŞ PERSPEKTIFINDE ENGELLI ISTIHDAMINA GENEL BIR BAKIŞ \\ $\ddot{O} \mathbf{z}$}

ILO'nun evrensel bir hedef olarak belirlediği insan onuruna yakışır iş, günümüzde tüm bireyleri ilgilendiren küresel bir gereksinim ve talep haline gelmiştir. Engellilere yönelik algı değişimi ile birçok ülkede engellilerin çalışma yaşamında karşılaştıkları problemlerle mücadeleye yönelikyeni stratejiler geliştirilmektedir. Geliştirilen sosyal politikalar; engellilerin yetenek ve durumlarına uygun olarak işe yerleştirilmelerini ve o işi ellerinde tutabilmelerine yardımcı olmayı amaçlamaktadır. Bu kapsamda çalışma hayatında engellilerin ekonomik, sosyal ve psikolojik olarak üst düzeyde tatmin elde edebilmeleri için gerekli tüm tedbirlerin alınması ve engellilerin toplumla bütünleşmeleri önündeki engellerin kaldırılması hedeflenmektedir. Belirlenen bu hedef "insan onuruna yakışır iş" kavramı ile amaçlanan hedeflerle büyük bir uyum göstermektedir. Çalışma ile bu uyuma ve engellilerin toplumla bütünleşmesi için istihdamın taşıdığı öneme dikkat çekilmektedir.

Anahtar Kelimeler: İnsan Onuruna Yakışır İş, Engelliler, İstihdam, Çalışma hayatı, ILLO

Makale Gönderim Tarihi: 08.01.2018, Kabul Tarihi: 12.02.2018

Doi: $10.26791 /$ sarkiat. 376313

* iD Bülent Ecevit Üniversitesi İİBF Kamu Yönetimi Bölümü, sanemberkun@mynet.com,

** IDUludağ Üniversitesi İİBF Çalışma Ekonomisi ve Endüstri İlişkileri Bölümü, ozlem@uludag.edu.tr 


\section{Introducton}

The notion of 'Decent work' describes the opportunity to be employed for a decent and productive job within an environment where the conditions of freedom, equality, security and dignity are provided for both men and women. The decent work stated to be an international objective by ILO has become a global need and demand concerning all individuals today. Multi lateral and broad objectives such as decent work opportunities provided under the circumstances of independence, equality, security and prestige for all the individuals throughout the world, eradication of poverty by enabling economically and socially sustainable development, realising social participation, social peace and social integration make it possible to improve the position of all the groups in a disadvantaged position within the labor market.

The disabled form a vast majority within the groups that have the risk of exclusion from the labor market. With the change in the overview on the disability, the participation of the disabled is seen as an objective that is desired to be achieved by all the countries and struggling strategies against the problems the disabled face are improved. The social policies developed aim to employ the disabled in accordance with their abilities and conditions and to make them hold it. Within this scope it is aimed to take all the necessary measures for the disabled to get the economical, social and psychological satisfaction and to remove the obstacles that prevent the social integration of the disabled. This particular objective is substantially compatible with the objectives of 'decent work'. In the study where the work life dimension of the change observed in the social status of the disabled; with the change in the perception towards the disabled, the compatibility between the notion of 'decent work' and the objectives correspond is pointed out. And on the background, there is the emphasis on the importance of employment in the social integration of the disabled.

\section{Decent Work with Its Dimendions, Aims and Components}

'Decent Work', determined to be an international aim by International Labor Organisation (ILO), in the widest sense, is used to characterize a general conceptual framework that refers to the employment and working rights of the individuals, conditions of occupational health and safety, social security opportunities and their right to express themselves through union participation or other presentation mechanisms (Işı ğıçok 2005: 3). This notion, which is characterised with 'decent work', 'convenient work', 'prestigious work', 'humanitarian work', 'humanely work' (İşveren 2003: 2; Kapar 2004: 185; Erdut 2003: 146) in the litterateur, is released to the public through a report with the title 'Decent Work' (Ghai 2003: 113) by Juan Somavia, the General Director of ILO in the $87^{\text {th }}$ International Labor Conference in 1999 which was organised by ILO. According to ILO, the decent work is defined as 'a work where the individuals' basic rights in working life are protected and a productive work which provides adequate income and social protection' (ILO 1999: 13); it is stated as a productive decent work under the conditions of independence, equality, safety and prestige for all the individuals. In this concept, it is possible to define the notion shortly and briefly as a 'decent and productive work within the conditions of freedom, equality, safety and honour for all the individuals' (Işı ğıçok 2005: 309-310). In other words, the work which is productive, with fair wages, workplace safety and the one that protects the families 
under the social protection extent and gives the opportunities to the people to express their worries, to become organised and to participate in the decisions that affects their life is referred with the notion of decent work.

According to ILO, this notion also means adequate employment; the access of all the individuals to the opportunities of income. For this reason, ILO regards the decent work both as an extremely important universal objective which draws the way to economically and socially balanced development, and an important and effective means which is efficacious to many other objectives. In other words, decent work for ILO has a reciprocal function being both the objective and the tool (Işı̆̆ıçok 2005: 4). In this context, decent work is considered to be an important component of ILO's innovation and the consistency for the changing conditions against the subsequent conditions and relationships brought by globalisation process (Kapar 2007: 2).

There are six basic dimensions of decent work (Anker et al 2003: 151-152). These are job opportunities, freedom to work, productive work, to be behaved fair and equal at the workplace, security and prestige, respectively. Thus, while the first of these dimensions, 'job opportunities', conceivefinding a proper job for the individuals looking for an easy work, it also involves all the economic activitiesof the ones working free lance, unpaid family workers, paid workers in formal or informal sector.

Freedom to work, the second of the dimensions, figures that employment happens as a result of the free will of the individuals. This dimension involves the freedom to work notably, forced and compulsory labor, slavery, determination of the minimum age to avoid the children to work and to ban the children under this age to work. This factor also involves the freedom of the workers to be organised and eventually to be protected against discriminatory attitudes. The third dimension is the productive work. Productive work refers to a work which is acceptable and sufficient for the workers to meet the needs of themselves and the dependent family members. Productive work also refers to a sustainable development under the globalisation circumstances and competitiveness for the enterprises and the countries.

The fourth dimension refers to a well balanced working and family life and the restraint of all the sorts of discrimination such as gender, race, colour, language, religion, national origin, disability etc. and particularly career and salary within all the working conditions. The fifth dimension, job security, refers to the protection of the workers' health against illnesses and/or various risks they face in working life, and adequate income and pension and other adequate financial protection supply. Finally, the sixth and the last dimension is prestige at work. Prestigious attitudes to the workers, their being listened by the authority and their participation to the decision making processes related with their own working conditions (Işığıçok, 2005: 4-5). When decent work is assessed within these six dimensions; it is clearly seen that the first two dimensions are related with the access to job opportunities and the other four dimensions are related with the decent work (Anker et al 2003: 152).

On the other hand, the decent work that is adopted by the ILO as a universal objective has become a global need and demand across the board nowadays. Without a doubt, considering the reality of decent work, there underlies multiple and wide objectives such as the removal of poverty by providing sustainable 
development, social participation, social peace and social integration. For this reason, it can be said that the objective of the decent work serves a wide range of purposes such as balanced economic and social development, alleviating poverty, social participation, social peace, and social integration all at once. In this respect, it would be the most correct approach to group 'objective' of the decent work notion into two basic groups as 'narrow and wide' (Işs̆ğıçok 2005: 23).

While providing decent employment under the circumstances of independence, security and prestige for all the individuals throughout the world, in other words, considering the quality of the employment besides the quantity, forms the narrow objective of decent work; eradication of poverty by meeting the conditions of economic and socially sustainable development, providing social participation, social peace and social integration to form the broad objective of decent work.

On the other hand, there are four main elements for decent work ( Ghai, 2003: 114, ILO, 1999:3). These are respectively,

1. Employment

2. Social Security

3. Basic rights related with Work Life and

4. Social Dialogue

It would not be wrong to call these basic elements that are characterized as the 'indicators' and the 'components' of decent work as 'the tools of decent work'.

The first element of decent work is 'employment'. Thus, productive employment is both the most important problem and the key factor in today's world. Therefore employment is still a compulsory and primary tool for creating and distributing wealth in our day. (Kapar 2004: 187). For its this characteristic, employment, has a centralised place among the duties of ILO; and ILO states that it is not possible to achieve the objectives related with decent work and life standards and social and economic development and a complete self realization without productive employment (ILO 1999: 21). According to ILO, the objective is not only 'to create employment' but also making this employment to be in an acceptable quality (ILO 1999: 4). This reveals that the quality and the quantity of the employment should be considered together (Işığıçok 2009: 316-317). In other words, not only the quantitativeness of the employment created is, but also its having an acceptable quality is important. In this context, some elements of employment stand out as an element of decent work (Kapar 2004: 188-189). First of these is creating decent work opportunities for all the individuals seeking jobs, whether it is a paid or freelance job. In other words, access to opportunities of employment is aimed and this aim reveals the necessity of creating new employment.

The second one is to provide the employment to be with the individual's free will. In this context employment should not include conditions like forced or mandatory working and slavery. Thirdly, use of child labor should be stopped and with this aim there should be a determined minimum age to stop using child labor and the working of the children under this age should be banned. Finally fourthly and lastly it should be made on the worker's free will to work part time or full time (Işı ğıçok 2005: 26).

The second element of decent work is 'social security'. There are various definitions for social security which is one of the basic needs of all the individuals. According to one of these definitions and in the broadest sense, social security is a 
body of institutions and built within a strict mutual adaptation aiming to secure today and tomorrow of the people of a country (Işı ğıçok 2009: 317). ILO attaches particular importance to social security as it is an element of decent work and while it sets off proper standards, it takes a leading part in this field by helping the member countries to build effective systems (ILO 1999: 30). However, it is a fact that various problems such as the increasing rates of unemployment, ageing, ascending single parent homes, increasing poverty rates, increasing mobility and the changes in the expectations for the role of social security systems today constrain social security systems. Therefore, social security as an element of decent work is needed more than ever. In other words, it is not possible to generate decent work and to protect the ones that exist without social security and social protection in today's global conditions of competition (Işı ğıçok 2009: 2009: 318).

The third important element of decent work is 'basic rights related with work life'. Basic rights related with work life are a complement that defines the extent, value and rules of the right and freedom to work. This issue which is the basic condition of economically and socially balanced development today is ILO's primary area of responsibility. Hence, according to ILO, every working individual has a set of rights in work life and the foremost of these are the right for collective bargaining and organisation against forced labor and protection right against discrimination (Işı̆̆ııçok 2009: 318). These basic rights which have been subject to many ILO contracts and recommendations until today are not only the most important contracts and recommendations that ILO has accepted, but they are also the most affirmed contracts by the ILO member countries (Erdut 2003: 58). The basic principles and rights related with those contracts that take part in the Declaration are majorly;

- Abolishing child labor completely,

- Abolishing all sorts of forced and mandatory work,

- $\quad$ Freedom to be organised and grant of bargaining rights,

- $\quad$ Abolishing discrimination in employment and profession(Işı̆ğıçok, 2005: 37).

Finally the fourth and the last element of decent work is 'social dialogue'. Social dialogue, in the broadest sense, is defined as the determination of basic economic and social policies and the participation of the employer and employee top organisation agents that are considered to be social stakeholders in the countries that adopt democratic political regime into the implementation with the other organisational interest group agents that exist in the society (Trebilcock 1994: 5). In other words, social dialogue is the only mechanism that assures social stakeholder agents and other interest group agents participate in the determination and implementation of economical and social policies in macro level. Concisely, it is defined to be a democratic debate and resolution process where social stakeholders come together on a volunteer basis (Ekin 1999: 374).

\section{Employment and The Necessity of The Employment of The Disabled}

Employment, when considered from the point of labour, is the sole tool of the individual to meet the needs of him/herself and of the dependant (Işığıçok 2005: 24). Employment, makes it possible for the individual to be safe in the society lived, self realization and to change into a producing status from a consuming status (Y1lmaz 2004: 11). Employment, besides being the principal determinant of the life standards, presents the individual an identity, effects social relationships and 
improves the self confidence (Jahoda 1982: 53). These positive effects the employment provides the individual have reflected on the regulations and the 'right to work' has entered both into national and international regulations as a very fundamental rightthat attaches various socioeconomic rights. Countries that accept the right to work are trying to carry out a wide range of practices including labor training, improving the working conditions and unemployment insurance (Koray 2008: 210). In this context, many countries carry out studies for generating conditions for decent work standards, active combat policies against unemploymentand develop mechanisms for 'everyone' to make use of these studies.

Disabled are an important majority among the groups with the risk of being excluded from the labor market. Besides, many countries develop strategies to change the viewpoint towards being disabled and to struggle against the problems the disabled face in working life. The notion of employment of the disabled refer to the policies for the employment of the Disabled who can work in labor market or state institutions and organisations with insurance through different ways and by other means (by Statutory Obligations and methods (Quaota Devices), Employment of the Disabled in Sheltered Workshops, Cooperative Operation Mode, Teleworking practices...) (Seyyar 2006: 325). Howeverthe fact that most of the disabled are unemployed in spite of all the intense work carried on in order to increase the employment of the disabled affirms that the disabled are in the front rows of the groups affected from the unemployment. Both the statistical and the qualitative findings show that the employment of the disabled is low (Ozawa at al 2006: 180). For instance, in a study published by Stodden, R.A. \&Dowrick between 1999 and 2000 that when compared with $80 \%$ of the general population in the USA which is a developed country, it is stated that only $30 \%$ of the disabled have a full time or a part time job (Stoddenand Dowrick, 1999-2000: 19-23). Therewithal, according to the 2002 data of National Statistical Institute; there are at least 8,5 million disabled in the United Kingdom, 6,5 million of these disabled people are at working age but only 3 million of them have a job (Giddens, 2008: 331-332). According to the United Nations (UN) reports the rate of unemployment among developed countries is between $50 \%$ and $60 \%$. This rate in developing countries reaches $80 \%-90 \%$ (United Nations, 2006; United Nations, 2007). Similarly, the report published by World health Organisation (WHO) and the World Bank in 2011 shows that the disabled face employment problems in many countries.

The policies developed on behalf of the disabled gained importance in Turkey like in all over the world. However the employment problems of the disabled haven't been solved yet. According to the Disabled Survey Turkey 2002, the labor force participation rate is very low. Only one out of five disabled participates in labor force. Besides, the unemployment rate for the women is high.

The data gained from the Disabled Survey, Turkey 2002 indicates that the disabled in Turkey are also out of the working life. However, the solution of the employment problems of the disabled would provide their selves and their families' participation in working life. The employment of the disabled is the only way for them to live independently and it would increase their life standards. More importantly, the government is supposed to create work areas and provide equal opportunities of employment for 'all' its citizens. This is among the duties of the state that cannot be avoided (Turkey Disabled Survey 2002). 
Disabled labour, as the production factor of an economy, is one of the groups that create total labor amount, namely human resource (Kuzgun 2009: 2451). Human resource in the country's economic progress should be used efficiently since it is vital (Subaşıŏlu, 2008: 404). Having physical or intellectual defect does not mean that the disabled cannot use their durable abilities (Alkan Meşhur 2004: 177-178). Making the disabled unproductive by pushing them out of the working life would result in a waste of human resource. However, being half of the human population, the disabled face the problems of unemployment and working life not only in developed countries but also the developing ones intensively. Active role of the disabled in working life is necessary for economic and social reasons. This necessity is the result of the change in the perspective to the individual, public and the state.

People need to work and bring-in in order to meet their natural, social and cultural requirements. This necessity is valid for the disabled too and it is also a right. When the disabled are employed compatible with their abilities and their condition, they wouldn't be consumers anymore and they could produce and be beneficial to the society. Besides, many disabled individuals are in need of treatments that require great expense. In this context, employment is considered to be the primary indicator of the material well being of the disabled (Burkhauserand Daly 1998: 17-29). Moreover, many countries with developed disabled policies have assistance programmes for the disabled who can work but face restrictions about the quantity of the jobs they can work (Mitra 2009: 15). Economic independence of the disabled would support a more healthy and quality living. Furthermore, both the dependent family members and the close relatives that take care of them would benefit from the income and social security opportunities provided by the employment of the disabled (Toplu 2009: 51-55; Alkan Meşhur 2004: 178).

Social reasons of the employment of the disabled are very important. Today, 'to work, to produce, to be employed' are among the prominent social values. The disabled want to work and producelike everyone impressed from the psychological and social values like sense of fulfilment obtained as a result of performing a task, the confidence of being a member of a group that is respected by the public, the need to feel confident, status and identity gained by work (Moos, 1986: 6; Karataş 2001: 141-147). Louis Haris states the meaning assigned to work and the importance of work for the disabled as follows (Haris 1987: 195-196);

The real determiner for making a choice between hope and hopelessness for the disabled is their working and not working. The ones that work feel themselves as part of the human race. The ones that do not work feel themselves left out, alone and useless most of the time.

Earning income is not sufficient enough for the disabled to access the life standards of the ones without disabilities for sure. It is a fact that the disabled are excluded by the social and physical environment in general. It requires removal of all the social, physical and economic obstacles for the disabled to take place in the society (Zarb et al 1993: 9-48).

3. The Change in The Perception Towards The Employment of The Disabled and Decent Work Within The Axis of The Models Indicating Disability 
Looking at the historic process, it is possible to say that four models indicated below intended for the description of the change observed in the social status of the disabled emerged consequentially (Okur et al 2010: 248).

'The traditional model that can be defined as the disability model which coincides with the communal living of the feudal period bases upon the information, view and practices determined culturally and solemn peculiar to the traditional structure.'(Okur and Erbil Erdoğan, 2010: 249). Within this model, disability is explained through solemn/ spiritual or on traditional bases and associated with destiny (Kolat 2010: 8). With this point of view, the disabled are sometimes seen as punished people and sometimes people who were chosen by the god and who should be treated well, compassionately and kindly (Okur et al 2010: 249).

Industrial Revolution had been the beginning of a quite difficult term and with this term the disabled had become more impoverished (Özgökçeler et al 2010: 36). With this term, 'high performance' had become an indispensable cult and the disabled were almost seen as 'useless', unnecessary beings under this expectations (Seyyar 2006: 13). The root cause of the development of this point of view is that the disabled who have their own working routine have difficulty in getting involved in this working order that requires pace in accord with the rhythm of the machines and a significant discipline (Barnes et al 1999: 18). Within the reality of the capitalism and the socialism practices of the $20^{\text {th }}$ century, the working individual is a 'complete, normal person'. The inevitable ideal under these circumstances is to 'normalize' the whole society (Demircioğlu 2010: 74).

Focal point of the medical model which began with the Industrial Revolution and effective even today is the physical and the biological condition of the disabled and with this model, disability is degraded into inadequacy (Priestley 1998: 75-79). The medical model considers disability as a situation that the individual would return to 'normal life' afterwards or could come close as much as possible, that could be fixed or more importantly that needs to be fixed (Aysoy 2004: 30-31).

The welfare state period and the political environment of this period which is a popular ground of the capitalist production process has created fundamental changes within the approach related with disability. State has seen the large masses who flagged under economic problems proper and justified (Göze 2009: 209-207). During this term, which has taken part as the golden age in the literature, the state interfered into the economy in order to build a fair social order and to increase the social welfare. During the welfare state period, social services have been a primary fields that the state intervention was dense (Şaylan 1995: 64-65) and the awareness about social problems raised. The social model developed within this environment differentiated the responsible authorities related with disabilities while it prescribed the perceiving of disability as a social problem (Okur e al 2010: 251-254).

According to the social model, disability is not a personal problem. It is a result of the social and cultural content and environment. It is a result of the social and cultural content and environment the individual is in. It arises from the society's not giving the necessary services for the disabled and not taking their needs into consideration (Karçkay, 2002: 15). Besides, disability is a result of social approaches and beliefs that cause results against the disabled (Burcu 2007: 53). All the obstacles for the integration of the disabled into the society should be removed and the disabled should be given the right to control their own lives (Scotch 1988: 164-165). 
Free cross-border circulation of capital has been accelerated with the globalisation and opportunities to implement large scale welfare policies and the financing abilities were eroded by the international competitive pressure herewith (Özsuca 2003: 134). Since the social policies are shaped by the orientation of global economic potentials, there has been a change from 'welfare state' to 'competitive state' (Özdemir 2007: 249). Significantly reduced institutions and an economic structure with limited means of employment opportunities has become prevailing all over the world (Ipsen et al 2005: 231). The reflection of this process into the labor market has been increased unemployment on the one hand and the dichotomy that took place in labor market with the occurrence of new working styles on the other (Çakır 2002: 89). 'The restricted areas and disappeared borders as a result of the globalisation process caused new threats in a wide range affecting the daily life (Bozkurt 2000: 104)'. This process that affected the welfare perception of the states significantly (SSenkal 2007: 364; Esping-Andersen, 2008: 55-100) brought a differentiation both in disability theory and in its social rights conception.

The human rights model accepts disability as a human rights problem and it assesses the negativity the disabled live as violation of human rights (Okur et al 2010: 247257). While the social model centres uponthe responsibilities of accessibility, social integrationand providing the participation, the human rights model opens the way to the emergence of human rights approach that the disabled have naturally (Ilter 2009: 35). The human rights model argues that all the chaos would disappear when 'human' is focused rather than finding any criterion (Çakmak 2006: 69).

It is possible to say that the language used and the economic practices of the human rights model do not have the equalizing and liberating dynamics. Barnes's evaluation for the model is in this aspect too (Barnes 2000: 1).

The emphasis on the individual rights of the disabled aims at providing the civil rights of the disabled and to enable their equal participation into society. However this emphasis is prone to overshadow the conflict about how to renew the terms of welfare.

As well as including some drawbacks, international institutions, international law and the states restructure their policies of disability largely within the scope of human rights. Concordantly with these developments, the scientistsalso consider disability as a human right problem (Okur et al 2010: 257).

The primary objective of being a contemporary society is to present equal rights and opportunities for every individual regardless of physical deficiencies (Kanbak et al 2009: 92). Providing prestigious and productive employment opportunitiesin an environment with conditions of independency, equality, security and caring is an important step inattaining this objective. What underlies the decent work is miscellaneous and broad aims like providing employment opportunities in conditions of independence, equality, security and prestige for both women and men throughout the world, eradication of poverty by providing sustainable economic and social development, social participation, social peace and social integration and improving the status of all the disadvantaged groups in the labor market.

As mentioned earlier, decent work for ILO states full access to the sources of income and points the way to an economic and socially balanced development. 
Regarding our study, this aim involves providing and increasing the employment of the disabled like everyone in the society. Thus, a career opportunity which is one of the dimensions of decent work draws attention to the importance of enabling proper job opportunities that can be found easily for 'all the individuals'. Likewise, besides being treated fair and equal and prevention of any kind of discrimination like gender, race, colour, language, religion, national origin, disability and particularly career and wages in all the conditions of work, a balance between work and family life is demanded too. This demand accords with the objective of social model and/or human rights model which is to provide equal opportunities put forward in the policies of employment of the disabled. With the decent work, it is significantly crucial for the disabled to be protected from illnesses and/or risks in working life, to be given adequate income and pension. Moreover, with prestige, it becomes possible for the disabled workers -like all the others -to face prestigious behaviours, to be heard by the relevant people, to participate into the decision processes related with their working conditions.

\section{Conclusion}

'Decent work', that has been identified as a universal objective by the International Labor Organisation (ILO), refers to the employee and employment rights, conditions of occupational health and safety, social security facilities and the right for self expression via unions or other mechanisms of representation and participation of all the individuals.Decent work conceptualizes independent, equal, safe and productive employment opportunities for everyone and it has become a global need and demand across the board today. Especially the states that accept the 'right to work' as a constitutional right seek to adopt many practices from the education of the labor to finding a job, from improving the conditions of work to unemployment insurance. In this context, there are some studies carried on like generating new fields of employment, providing education in order to increase the employability of labour, implementing active struggle policies towards unemployment and mechanisms to provide everyone benefit from these studies are improved.

The disabled have been a great majority among the groups with the risk of exclusion from labor market and they have faced many social and economic problems in every period of history. Reducing this negative effect has been perceived as financial and in-kind aid until the recent past. However, with the change in the perception towards the disabled, new strategies have been developed in order to struggle with the problems the disabled face in many countries. Social policies developed accordingly aim at employing the disabled into jobs proper with their skills and condition and at their holding that job.

Not only the medical approach but also the social and human rights based approach picturing have been effective in the change within the perception towards the disabled. 'Although the notion of 'rights of the disabled' is perceived as a category of rights that belong to disabled individuals, promoting the disabled benefit from all the fundamental rights and freedoms whole and equal like the other individuals and strengthening the respect to human dignity is determined with this notion' (Rights of the Disabled Analysis Report 2013: 2). This objective in the employment dimension reciprocates with the notion of decent work. Because, multi lateral and broad objectives like providing opportunities of decent employment providing independence, equality, security and prestige, eradication of poverty by providing 
economic and social sustainable development, social participation, social peace and social integration underlie decent work. Therefore, 'decent work' would bring a substantial recovery for the working conditions of everyone in the society particularly for the disadvantaged groups that the disabled take part in.

In this context, employment surveys that can be used to make comparisons at an international level should be carried out and in the light of the results obtained accessible job quality data should be improved for the decent work employment opportunities to become prevalent (Burchell et al 2014: 474). Hereby, the countries participated the survey would find the opportunity to evaluate the efficiency of legal regulations and social policies. Lack of data is substantially more serious for the disabled. Despite the vigorous efforts of World Health Organisation and International Labor Organisation, there is lack of up to date data showing the number and the condition of the disabled in many countries. Including the quality and the quantity of the disabled within the data base that can be used to make comparisons in an international level would significantly contribute to the success of the social policies to be developed. Besides, the disabled people's benefiting from the developments in computer and communication technologies at a high level should be provided. Because the computer and communication technologies today remove the need to be mobile since they provide access to the information and services where available. Thus, the disabled would have a chance to have a decent work without being exposed to prejudice and discriminatory behaviour in an accessible work environment (Berkün 2013: 66-74). Furthermore, developing alternative employment methods to provide the active participation of the disabled into work life and providing a proper environment and conditions for the new methods developed would be a small yet an important step taken for their social integration.

\section{References}

Alkan Meşhur, Filiz H. (2004) "Engellilerin Çalışma Yaşamına Katılma Gerekliliği ve Uygulanan İstihdam Politikalarının Değerlendirilmesi", Öz-Veri Dergisi, (I),2, pp. 176-183.

Andersen, Gøsta Esping “Altın Çağ Sonrası? Küresel Bir Ekonomide Refah Devleti İkilemleri” (2008) Sosyal Politika Yazıları, 3.b., Der: Ayşe Buğra ve Çağlar Keyder, İletişim Yayınları, , İstanbul,pp. 55-100.

Anker, Richard et al, "Measuring DecentWorkWith Statistical Indicators" International LabourReview, Vol: 142, No: 2,2003.

Aysoy, Mehmet (2004) Avrupa Birliği Sürecinde Özürlüler Politikası, Açı Kitaplar1, İstanbul.

Barnes, Helen (2000) Working For a Living? Employment, Benefitsandthe Living Standards of Disabled People, The Policy Pres, Bristol.

Barnes, Colin et al (1999) Exploring Disability, Polity Press, Cambridge.

Berkün, Sanem (2013) Özürlülerin İstihdamında Ev Esaslı Tele Çalışma (Evde Tele Çalışma): Bursa İli Belediyelerinden Örnekler, TC Çalışma ve Sosyal Güvenlik Bakanlığı Çalışma ve Sosyal Güvenlik Eğitim ve Araştırma Merkezi Yayını, Yayın No. 38, Ankara. 
Bozkurt, Veysel (2000) “Küreselleşmenin Toplumsal Sonuçları”, Küreselleşmenin Insani Yüzü, Der: Veysel Bozkurt, İstanbul, pp. 93-114.

Burchel, Brendan et al (2014) "The Quality of Employmentand Decent Work: Definitions, Methodologies, and Ongoing Debates", Cambridge Journal of Economics, 38, pp.459-477.

Burcu, Esra (2007) Türkiye'de Özürlü Birey Olma Temel Sosyolojik Özellikleri ve Sorunları Üzerine Bir Araştırma, Hacettepe Üniversitesi Yayınları, Ankara.

Burkhauser, Richard V. Et al (1998) "DisabilityandWork: the Experiences of Americanand German Men", FRBSF Federal Reserve Bank of San Francisco EconomicReview, Number:2, pp. 17-29.

Çakır, Özlem (2002) "Sosyal Dışlanma”, Dokuz Eylül Üniversitesi Sosyal Bilimler Enstitüsü Dergisi, (4)3, pp. 83-104.

Çakmak Naci Münci (2006) Türk Kamu Hukuku Açısından Engellilerin Hukuki Statüsü, Ankara Üniversitesi Sosyal Bilimler Enstitüsü Kamu Hukuku (İdare Hukuku) Anabilim Dalı (Yayınlanmamış Doktora Tezi), Ankara.

Demircioğlu Mağdule (2010) Üretim Sürecinde Sakat Emeği, Kibele Yayınları, İstanbul.

Engelli Hakları Inceleme Raporu (2013) Türkiye Büyük Millet Meclisi İnsan Hakları İnceleme Komisyonu

Ekin Nusret, Küreselleşme ve Gümrük Birliği, İstanbul Ticaret Odası, Yayın No:1999-47,İstanbul 1999

Erdut, Zeki (2003) Küreselleşme Bağlamında Uluslararası Sosyal Politika ve Türkiye, Dokuz Eylül Üniversitesi Yayınları, 2. Basım, İzmir.

Ghai, Draham "DecentWork: ConceptandIndicators" International LabourReview, Vol:142, No:2, 2003.

G1ddens, Anthony (2008) Sosyoloji, 1.b., Kırmızı Yayınları, İstanbul.

Göze, Ayferi (2009) Liberal, Marxiste, Faşist, Nasyonal, Sosyalist veSosyal Devlet Sistemleri, Beta Yayınevi, İstanbul.

Haris, Louis (1987) Inside America, Vintage 1st Edition, New York.

Ipsen, Catherine et al (2005) "Self-Employmentfor People WithDisabilitiesEnhancing Services Through InteragencyLinkages",Journal Of DisabilityPolicyStudies, Volume:15, No: 4, pp. 231-239.

Işı̆̆ıçok, Özlem (2005) XXI. Yüzyılda İstihdam ve İnsana Yakışır İş, Ezgi Kitabevi, Bursa.

Işı̆̆ıçok, Özlem (2009) "Küreselleşme Sürecinde İnsana Yakışır İş" İstanbul Üniversitesi İktisat Fakültesi, Sosyal Siyaset Konferanslart 56.Kitap, İstanbul

Işığıçok, Özlem vd. (2011), "Özürlü İstihdamında Bir Hak olarak İnsana Yakışır İşi Sorgulamak”, Prof. Dr. Tankut Centel'e Armağan, İstanbul Üniversitesi Hukuk Fakültesi, İstanbul

ILO (1999) DecentWork, International Labour Conferance, 87th Session 1999, Report ofTheDirector General, Geneva.

İşveren Dergisi, (TİSK) (43), 2, Kasım 2004 
İlter, Erem (2009) "Birleşmiş Milletler Özürlü Kişilerin Hakları Sözleşmesi’nin Türkiye'nin Özürlülük Politikasına Katkısı”, TC Başbakanlık Özürlüler İdaresi Başkanlığı, (Yayımlanmamış Özürlüler Uzmanlığı Tezi) Ankara.

Jahoda, Marie (1982) EmploymentandUnemployment, Cambridge University Pres, Cambridge.

Kapar, Recep (2007) “ Uygun İş Açığı: İnsana Yaraşmayan İşler”, TTB Mesleki Sağllk ve Güvenlik Dergisi, Sayı:29

Kapar, Recep (2004) "Uygun İş Bağlamında Çalışan Yoksullar”, İktisat Fakültesi Sosyal Siyaset Konferanslart 48.Kitap, İstanbul Üniversitesi Yayın No: 4531, İstanbul.

Kanbak, Ayşegül vd. (2009) "Engelli İstihdamına Yönelik Yerel Eksenli Bir Çözüm Önerisi: Bizimköy Örneği”, Kocaeli Üniversitesi İktisadi ve İdari Bilimler Fakültesi Dergisi, 7, pp. 91-108.

Karataş, Kasım. (2001) "Özürlülerin İstihdamı ve Çalışma Yaşamında Karşılaşılan Sorunlar" Görme Özürlüler İçin Rehabilitasyon Deneyimleri, Yeni Rehabilitasyon Politikaları ve Meslek Tanımlart, (Der:) Kasım Karataş. Körler Federasyonu Yayını, No: 4 Ankara, pp. 141-152.

Karçkay, Keziban (2002) Toplumsal Bir Kimlik Olarak Özürlülük, TC Başbakanlık Özürlüler İdaresi Başkanlığı, (Yayımlanmamış Özürlüler Uzmanlığı Tezi) Ankara.

Kolat Serkan (2010) Avrupa Birliği Sosyal Politikası Çerçevesinde Özürlülere Yönelik Ayrımcılıkla Mücadele ve Türkiye'deki Yansımaları, TC Başbakanlık Özürlüler İdaresi Başkanlığı Yayını, Yayın No: 49, Ankara.

Koray, Meryem (2008) Sosyal Politika, 3. b., İmge Kitabevi, Ankara.

Kuzgun, İnci (2009) “Türkiye'de Özürlülerin Ücret Karşılığı İstihdamını Belirleyen Değişkenler ve Öneriler”, Journal of Yasar University, (4)15, pp. 24512466.

Mitra, Sophie (2009) "TemporaryandPartialDisability Programs in Nine CountriesWhat Can the United StatesLearnFromOtherCountries?", Journal of Disability Policy Studies, Volume:20, Number:1, pp. 14-27.

Moos Rudolf H. (1986) "Work as a Human Context",Psychologyand Work : Productivity, Change, andEmployment, (Editor:) Michael S. Pallakand Robert O. Perloff, Washington, D.C. :AmericanPsychologicalAssociation.

Okur, Nejla vd. (2010) "Sosyal Haklar ve Özürlüler: Özürlülük $\quad$ Modelleri Bağlamında Tarihsel Bir Değerlendirme", II. Sosyal Haklar Ulusal Seтроzуити, Denizli, ss.245-263. http://www.sosyalhaklar.net/2010/2010index.htm, (18. 07.2011).

Ozawa, Martha N. et al (2006) "Work Statusand Work Performance of People With Disabilities" Journal Of Disabılıty Polıcy Studies, Volume: 17, No: 3, pp. 180-190.

Özdemir, Süleyman (2007) Küreselleşme Sürecinde Refah Devleti, 2.b., İstanbul Ticaret Odası Yayınları, Yayın NO: 2007-57, İstanbul.

Özgökçeler, Serhat vd. (2010) “Özürlüler Kanunu'nun Sosyal Model Açısından Değerlendirilmesi”, İşletme ve Ekonomik Araştırmalar Dergisi, (1)1, pp. 33-54. 
Özsuca, Şerife (2003) "Küreselleşme ve Sosyal Güvenlik Krizi”, Ankara Üniversitesi $S B F$ Dergisi, (58)2, pp. 133-152.

Priestley, Mark (1998) "ConstructionsandCreations: İdealism, MaterialismandDisabilityTheory" Disabilityand Society, Volume: 13, Issue: 1, pp.75-94.

Scotch, Richard K. (1988) "Disability as theBasisfor a SocialMovement: AdvocacyandthePolitics of Definition”. Journal of SocialIssues, Volume: 44, Issue: 1, pp. 159-172.

Seyyar, Ali (2006) Özürlülere Adanmış Sosyal Politika Yazıları, Adapazarı Büyükşehir Belediyesi Yayını, Adapazarı.

Subaşıŏlu, Fatoș (2008) “Üniversitelerin Bilgi ve Belge Yönetimi Bölümleri’nin "Engellilik Farkındalığı" Üzerine Bir Araştırma”, Bilgi Dünyası, (9)2, pp.399-430.

Stodden Robert A. et al (1999-2000) "PostsecondaryEducationandEmployment of AdultswithDisabilities”, American Rehabilitation, Volume:25, No:3, pp. 19-23.

Şaylan Gencay (1995) Değişim Küreselleşme ve Devletin Yeni İşlevleri, İmge Kitabevi Yayınları, Ankara.

Şen, Sabahattin (2009) "Insanca İş ve İş̧ Denetimi Boyutuyla Ölçülebilirliğì", (www.sosyalhaklar.net/2009/bildiri/sen.pdf) (15.10.2014 tarihli görünüm)

Şenkal, Abdülkadir (2007) Küreselleşme Sürecinde Sosyal Politika, 2.b., Alfa Yayınları, İstanbul.

Toplu, Aslı (2009) “Sosyal Dışlanma Perspektifinden Türkiye'de Özürlü İstihdamı", Gazi Üniversitesi Sosyal Bilimler Enstitüsü Çalışma Ekonomisi ve Endüstri İlişkileri Ana Lisans Tezi), Ankara.

Trebilcock, Anne (1994) Towards Social Dialogue: TripartiteCooperationInNationalEconomicandSocialPolicyMaking, International Labour Office, Geneva.

Türkiye Özürlüler Araştırması Bilim Dalı (Yayınlanmamış Yüksek http://www.ozida.gov.tr/arastirma/oztemelgosterge.htm (06. 02. 2012).

United Nations, "SomeFactsaboutPersonswith Disabilities",2006, http://www.un.org/disabilities/convention/pdfs/factsheet.pdf , (06. 02. 2012)

United Nations, "Human RightsandPersonswithDisabilities",2007, http://www.un.org/esa/socdev/enable/rights/humanrights.htm, (06. 02. 2012).

Yılmaz, Zuhal (2004) "Çalışan Özürlülerin İş Yaşamında Karşılaştıkları Sorunlar ve Bunları Etkileyen Etmenler", Öz-Veri Dergisi, Ankara, Cilt I, Say1 : 2http://www.ozida.gov.tr/ozveri/ov2/ov2calisanozurlusorunlari.htm , (24. 07.2011).

Zarb, Gerryand et al (1993) Ageing With a DisabilityWhat Do TheyExpectAfterAllTheseYears?, University of Greenwich, London. 